\title{
REAKTUALISASI KONSEP MAHRAM DALAM HADIS TENTANG PERJALANAN WANITA PERSPEKTIF MAQASID AL-SHARIAH
}

\author{
Holilur Rohman
}

Fakultas Syari'ah dan Hukum UIN Sunan Ampel Surabaya. E-mail: elrahman10@gmail.com

\begin{abstract}
This study discusses the actualization of the concept of mahram in the hadith about the maqasid al shari'ah. The focus of this study are: How is the editorial of the prophetic hadith about the probibition of women's travel without mahram? What do the scholars say about addressing women's travel? How is the actualization of the concept of mabram in the course of women on maqasid al shariah? This research is a library research with a qualitative descriptive-analytical type and with a philosophical approach. The conclusion of this study, that the reason bebind the probibition of women not allowed to travel alone without mahram is a concern for women's safety when they are alone. The statement like this, the law of the obligation of mahram for women traveling is contextual, because maqasid al shariah, within the context of this obligation, is to provide protection and security to women. Whereas the command to include mabram in the journey of women is basically one of the observations to protect women from unwanted possibilities. Whereas the trustee can be replaced with another guardian in the form of a protection mechanism for the community, both individually and collectively, among others through legal rules, legislation, and public policies that can lead to safer and protected trip.
\end{abstract}

Keywords: Mahram, Women's journey, Maqasid al Shariah

Abstrak: Penelitian ini membahas tentang reaktualisasi konsep mahram dalam hadis tentang perjalanan wanita perspektif maqasid al-shariah. Fokus penelitian ini adalah: Bagaimana redaksi hadis nabi tentang pelarangan perjalanan perempuan tanpa mahram? Bagaimana pendapat para ulama' menyikapi perjalanan perempuan? Bagaimana reaktualisasi konsep mahram dalam perjalanan perempuan perspektif maqasid al-shariah? Penelitian ini adalah penelitian pustaka. Penelitian ini juga berjenis kualitatif yang bersifat deskriptif-analitis. Pendekatan penelitian ini menggunakan pendekatan filsafat. Kesimpulan penelitian ini, bahwa alasan di balik larangan perempuan tidak boleh bepergian seorang diri tanpa mahram adalah kekhawatiran terhadap keamanan perempuan saat bepergiaan seorang diri. Dalam pernyataan ini seperti ini, hukum kewajiban mahram bagi perempuan bepergian bersifat kontekstual, karena maqasid al-syariah dari kewajiban ini adalah untuk memberikan perlindungan dan keamanan kepada perempuan. Sedangkan perintah penyertaan mahram dalam perjalanan perempuan pada dasarnya adalah

AL-HUKAMA

The Indonesian Journal of Islamic Family Law

Volume 08, Nomor 02, Desember 2018; ISSN:2089-7480 
salah satu wasilah untuk melindungi perempuan dari kemungkinankemungkinan yang tidak dikehendaki. Sedangkan wasilah tersebut bisa diaganti dengan wasilah lain berupa mekanisme perlindungan bagi masyarakat, baik secara individu maupun kolektif antara lain melalui aturan-aturan hukum, perundang-undangan, dan kebijakan-kebijakan publik yang bisa membujat perjalanan lebih aman dan terlindungi.

Kata Kunci: Mahram, Perjalanan Wanita, Maqasid al-Syariah

\section{Pendahuluan}

Kehadiran Islam merupakan berkah bagi umat manusia, termasuk di dalamnya adalah perempuan. Dulu perempuan berada di kelas kedua di bawah laki-laki sehingga banyak perlakuan yang tidak menyenangkan dirasakan oleh perempuan. Ketika Islam hadir, Islam mengangkat derajat perempuan setinggi-tingginya. Perempuan pun berhak mendapat warisan, dilarang pula melakukan kekerasan dalam rumah tangga tanpa alasan yang dibenarkan, poligami mulai dibatasi hanya sampai empat orang, dan aturanaturan lain yang sangat memihak terhadap perempuan. Al-Qur'an dan dan as-Sunnah lah yang menjadi pioner dan pahlawan sejati untuk merealisasikan semuanya.

Akan tetapi sistem patriarki-misoginis tidak bisa dihilangkan begitu saja. Dengan menyandarkan pada beberapa hadis Nabi, sebagian ulama' tetap menomerduakan wanita dalam struktur masyarakat. Lalu muncullah pelarangan terhadap perempuan untuk melakukan perjalanan tanpa didampingi mahramnya. Inilah yang sampai saat ini menjadi problem dalam diskursus hukum Islam. Banyak hadits yang melarang wanita bersafar/bepergian tanpa mahram, di antaranya adalah hadis riwayat 'Abdullah bin 'Umar, bahwasanya Nabi SAW bersabda:

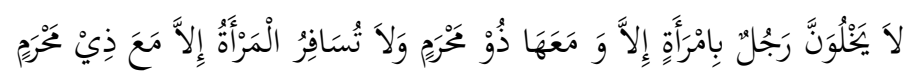

Janganlah sekali-kali seorang lelaki menyendiri dengan seorang wanita kecuali wanita itu disertai mahramnya, dan tidak boleh seorang wanita bepergian kecuali bersama mahram.1

Deskripsi di atas cukuplah menunjukkan adanya problem dan pertentangan antara kenyataan pada masa sekarang di mana wanita

1 Muslim bin al-Hajjaj Abu al-Hasin al-Qushairi al-Naisaburi, Sabih Muslim, juz 2, Maktabah Shamilah, 978 
biasa melakukan perjalanan tanpa didampingi mahramnya, dengan hadis-hadis Nabi yang melarang perempuan melakukan perjalanan tanpa mahram. Jika meangplikasikan bunyi teks hadis tentang pelarangan di atas, maka akan terjadi persoalan serius mengenai gerak dan aktifitas perempuan di ranah publik. Banyak aktifitas perempuan yang sulit dijalankan jika harus selalu didampingi seorang mahram, seperti anak perempuan yang pergi dari desanya ke kota untuk melanjutkan kuliah di kampus dan bertempat tinggal di sekitar kampus tersebut dalam jangku waktu yang lama, begitu juga para pejabat atau pegawai perempuan yang terkadang ditugaskan untuk melaksanakan perjalanan dinas selama berhari-hari di luar kota, termasuk juga para pengusaha perempuan yang sering melakukan perjalanan ke laur kota bahkan ke luar negeri untuk mengembangkan usahanya, tidak lupa pula para Tenaga Kerja Wanita yang jumlahnya begitu banyak tersebar di berbagai Negara, dan banyak aktifitas perempuan lain yang mengharuskannya melakukan perjalan tanpa disertai mahram. Tentu deskripsi di atas tidak bisa di padang sebelah mata.

Disinilah letak problem dalam penelitian ini. Di satu sisi, mengaplikasikan bunyi teks hadis tanpa pertimbangan kenyataan yang sudah berlaku sama saja akan membuat kesulitan yang tidak bisa terhindari. Di sisi lain, ada hadis Nabi yang melarang secara tegas aktifitas perjalanan perempuan tanpa didampingi mahram. Pada ranah inilah penelitian ini sangat urgen untuk dilakukan agar tidak terjadi benturan keras antara bunyi teks hadis Nabi dan kenyataan yang sudah berlangsung di tengah-tengah masyarakat. Perlu penelitian lebih lanjut untuk mendamaikan dua sisi tersebut agar lahir solusi terbaik sesuai metode penetapan hukum yang berlaku.

Jenis penelitian pada penulisan makalah ini adalah penelitian pustaka, yaitu berusaha menelusuri dan menganalisis hadis - hadis Nabi yang berkaitan dengan pelarangan perempuan melakukan perjalanan tanpa mahram, dan juga penelurusan beberapa kitab yang memuat pendapat-pendapat ulama' tentang perjalanan perempuan. Penelitian ini juga berjenis kualitatif yang bersifat deskriptif-analitis, yaitu berusaha mendeskripsikan hadis Nabi dan pendapat ulama' yang berkaitan dengan. Isi dari data yang diperoleh dianalisis dan 
diinterpretasi menggunakan teori maqasid al-syari'ah untuk melakukan kajian dan penafsiran ulang terhadap hadis dan Nabi tersebut karena adanya perbedaan situasi, kondisi, waktu dan tempat.

Pendekatan penelitian ini menggunakan pendekatan filsafat, artinya memahami teks tidak sekedar membaca terjemahnya saja, akan tetapi mencari makna sedalam-dalamnya dari teks hadis Nabi dan pendapat ulama' agar ditemukan maksud dan tujuan yang terkandung dalam teks.

\section{Konsep Mahram}

Adanya mahram diharapkan bisa menjadi penjamin keamanan bagi perempuan dari gangguan apapun, baik dari gangguan sesama manusia ataupun dari gangguan selain manusia. Lalu tentang siapakah mahram perempuan itu, sebenarnya di dalam al-Qur'an tidak dijelaskan secara konkrit tentang mahram perempuan. Penjelasan yang biasanya dipaparkan adalah para mahram bagi lakilaki sebagaimana dijelaskan dalam al-Qur'an surat an-Nisa' ayat 23, yaitu:

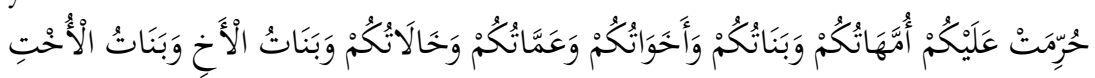

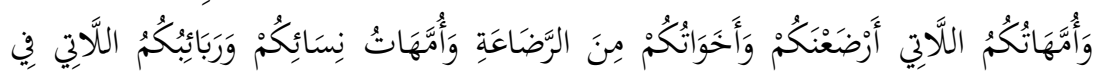

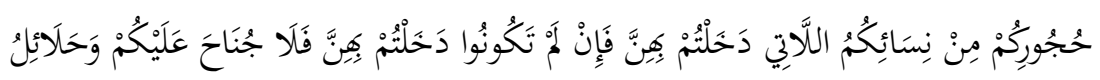

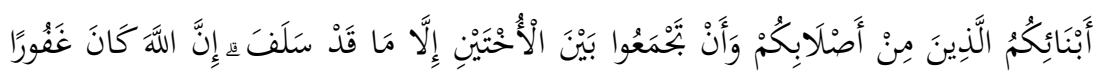

Diharamkan atas kamu (mengawini) ibu-ibumu; anak-anakmu yang perempuan [281]; saudara-saudaramu yang perempuan, Saudara-saudara bapakmu yang perempuan; Saudara-saudara ibumu yang perempuan; anakanak perempuan dari saudara-saudaramu yang laki-laki; anak-anak perempuan dari saudara-saudaramu yang perempuan; ibu-ibumu yang menyusui kamu; saudara perempuan sepersusuan; ibu-ibu isterimu (mertua); anak-anak isterimu yang dalam pemeliharaanmu dari isteri yang Telah kamu campuri, tetapi jika kamu belum campur dengan isterimu itu (dan sudab kamu ceraikan), Maka tidak berdosa kamu mengawininya; (dan dibaramkan bagimu) isteri-isteri anak kandungmu (menantu); dan menghimpunkan (dalam 
perkawinan) dua perempuan yang bersaudara, kecuali yang Telab terjadi pada masa lampau; Sesunggubnya Allah Maha Pengampun lagi Maha Penyayang.

Oleh karena itu, mahram bagi perempuan adalah kebalikan dari mahram bagi laki-laki, yaitu setiap orang yang diharamkan menikahinya dengan pengharaman yang bersifat selamanya, baik karena hubungan kekerabatan, persusuan atau karena hubungan pernikahan. Rinciannya sebagaimana berikut:

1. Mahram kekerabatan

a. Ayah, kakek dan seterusnya ke atas, baik dari pihak ayah maupun ibu.

b. Anak laki-lakinya, anak laki-laki puteranya, anak laki-laki puterinya dan seterusnya ke bawah.

c. Saudara laki-laki (seayah seibu), saudara laki-lakinya yang seayah dan saudara laki-lakinya yang seibu.

d. Anak laki-laki saudara laki-laki sekandung, anak laki-laki saudara laki-lakinya yang seayah dan anak laki-laki saudara laki-lakinya yang seibu.

e. Anak laki-laki saudara perempuan yang sekandung (seibu seayah), anak laki-laki saudara perempuannya yang seibu.

f. Pamannya (saudara laki-laki ayahnya) baik saudara sekandung atau saudara laki-laki ayah yang seayah atau saudara laki-laki ayah yang se-ibu.

g. Saudara laki-laki ibu, baik saudara se-kandung atau saudara laki-laki ibu yang seayah, atau saudara laki-laki ibu yang seibu. 2

2. Mahram karena hubungan persusuan

Mahram seorang wanita karena persusuan sama dengan mahramnya karena hubungan kekerabatan, berdasarkan sabda Nabi SAW:

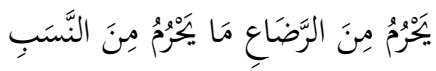

"Diharamkan karena sebab (saudara) per-susuan apa-apa yang diharamkan karena sebab nasab (kekerabatan)." 3

2 Muhammad Nawawi, Taushib 'ala ibni qasim, (Surabaya: Mahkota, tt), 201.

3 Ibn Rushd, Bidayah al-Mujtahid, juz 2, (Surabaya: al-Hidayah, tt), 26. Dalam kitab ini Ibnu Rush menjelaskan panjang lebar tentang perbedaan pendapat ulama' 
3. Mahram (bagi seorang wanita) karena pernikahan

Mahram bagi seorang wanita karena sebab pernikahan adalah:

a. Anak laki-laki suami dan putera-puterinya, putera-putera (anak laki-laki) dari anak perempuan suami dan seterusnya ke bawah, sama saja apakah mereka itu dari isteri yang sebelumnya (yang telah diceraikan) atau masih dalam ikatan perkawinan dengan atau dari isteri yang sesudahnya.

b. Ayah suaminya (mertua laki-lakinya), kakeknya dan seterusnya ke atas, sama saja apakah kakeknya itu dari pihak ayah suami atau ibu suaminya.

c. Suami anak perempuannya (menantu laki-lakinya) dan suami cucu perempuannya, baik cucunya itu dari anak laki-lakinya atau dari anak perempuannya, dan seterusnya ke bawah.

d. Ketiga orang yang disebutkan ini tetap menjadi mahramnya, hanya sekedar dengan melaksanakan akad nikah, sehingga kalaupun suaminya telah meninggalkannya karena mati atau karena talak (mentalaknya) atau karena fasakh (dipisahkan pernikahannya), maka mereka (ketiga golongan diatas) tetap sebagai mahram baginya (bagi wanita tersebut).

e. Suami ibu dan suami nenek dan seterusnya ke atas, namun demikian suami tersebut tidak bisa menjadi mahram bagi anak-anak perempuan isterinya, hingga dia telah mengumpuli isterinya tersebut. Jika dia telah mengumpulinya barulah dia menjadi mahram bagi puteri isterinya dan puteri cucunya, baik puteri itu dari suami sebelumnya atau suami sesudahnya, meskipun nantinya dia menceraikan isterinya itu. Jika dia hanya sekedar menjalankan akad nikah dengan seorang wanita, lalu dia menceraikannya sebelum mengumpulinya, maka dia tidak bisa menjadi mahram bagi anak perem-puan dan cucu perempuan mantan isteri-nya tersebut. 4

\section{Hadis-Hadis yang Melarang Perempuan Bepergian Tanpa Mahram}

terkait beberapa hal, diantaranya kadar keharaman dari persusuan, umur menyusui, dan lain-lain.

4 Sayyid Sabiq, Fiqh al-Sunnah juz 1I, 249. 
Ada Banyak hadits yang menjelaskan tentang status hukum perjalanan tanpa disertai mahramnya. Dalam beberap hadis dalam kitab Sahih al-bukhari dan Muslim dijelaskan tentang larangan wanita bersafar/bepergian tanpa mahram, di antaranya adalah:

1. Dari 'Abdullah bin 'Umar, bahwasanya Nabi SAW bersabda:

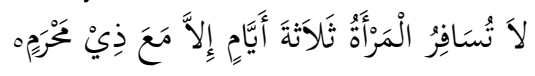

Tidak boleh seorang wanita mengadakan perjalanan selama tiga hari, kecuali bersama mahram.

2. Dalam riwayat Muslim dari hadits Abu Said al-Khudri, Rasulullah SAW bersabda:

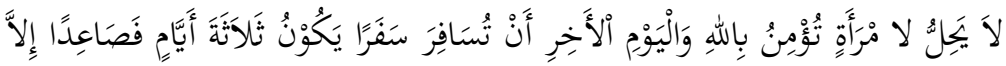

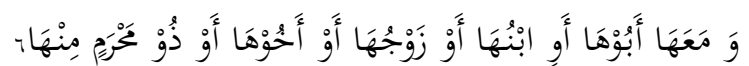

Tidak halal bagi seorang wanita yang beriman kepada Allah dan hari akhir untuk mengadakan perjalanan yang memakan waktu selama tiga hari lebih, melainkan ia harus didampingi oleh ayahnya, anaknya, suaminya, saudaranya, atau mahramnya.

3. Hadits 'Abdullah Ibnu 'Abbas, ia berkata: "Aku mendengar Rasulullah SAW berkhutbah, beliau berkata:

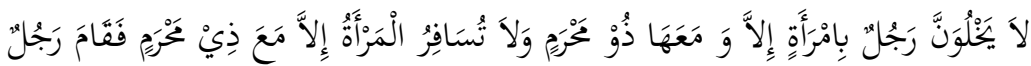

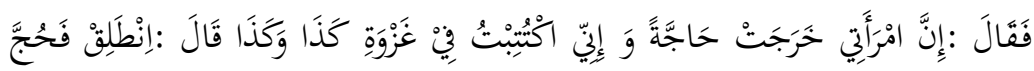

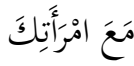

Janganlah sekali-kali seorang lelaki menyendiri dengan seorang wanita kecuali wanita itu disertai mahramnya, dan tidak boleh seorang wanita bepergian kecuali bersama mahram, maka bangkitlah seorang lelaki lalu berkata: 'Sesungguhnya isteriku telah keluar untuk menjalankan ibadah haji, sementara aku telah diwajibkan untuk mengikuti sebuah peperangan', maka beliau bersabda: 'Pergilah dan kerjakan haji bersama isterimu.7

5 Abi Abdillah Muhammad Bin Isma'il Al-Bukhari, al-Jami' al-Sabih, juz 4, Maktabah Shamilah, 331.

6 Muslim bin al-Hajjaj Abu al-hasin al-Qushairi al-Naisaburi, Sabih Muslim, juz 2,

Maktabah Shamilah, 977.

7 Ibid., 978. 
4. Rasulullah SAW bersabda:

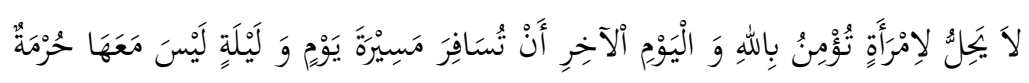

Tidak halal bagi seorang wanita yang beriman kepada Allah dan hari akhir bepergian sejarak perjalanan sehari semalam tanpa disertai mahramnya.

5. Rasulullah SAW bersabda:

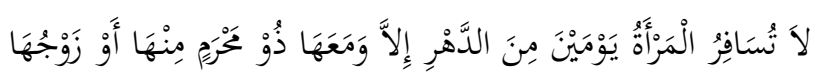

Tidak boleh seorang wanita bepergian selama dua hari dari suatu masa, kecuali disertai oleh mahramnya atau suaminya. 9

\section{Perbedaan Ulama' tentang Perjalanan Perempuan}

Dalam diskusi fiqh seringkali orang hanya mengenal pandangan bahwa seorang perempuan yang akan bepergian dalam jangka waktu tertentu, terlepas untuk urusan apapun diwajibkan ditemani keluarga dekat yang disebut mahram, sebagaimana dijelaskan di beberapa hadis di atas. Keharusan mahram dampingan ini seringkali dihadirkan tanpa ada diskusi konteks sosial, alasan hukum, ragam teks-teks hadits yang menjadi dasar, maupun ragam pandangan para ulama fiqh itu sendiri.

Pengetahuan mengenai konteks suatu hukum dan ragam pandangan ulama sangat penting untuk memahami secara baik karakter hukum tersebut. Tanpa pengetahuan yang memadai dan dalam kealpaan perspektif yang ramah perempuan, misi perlindungan dalam konsep mahram pasti akan terlupakan ketika mengurai teks hadits dan pandangan hukum terkait penjelasan konsep ini.

Beberapa hadis pelarangan perempuan keluar tanpa mahram oleh beberapa ahli fiqh dijadikan dasar pengekangan dan domestifikasi perempuan. Penjelasan Imam as-San'ani (w. $1182 \mathrm{H} / 1850 \mathrm{M}$ ) terhadap teks hadits ini dalam kitab Subul al-Salâm,

8 Abi Abdillah Muhammad Bin Isma'il Al-Bukhari, al-Jami' al-Sahih, juz 1, Maktabah Shamilah, 368.

9 Muslim bin al-Hajjaj Abu al-Hasin al-Qushairi al-Naisaburi, Sahih Muslim, juz 2, Maktabah Shamilah, 975. 
bahwa larangan ini terkait fitnah tubuh perempuan, juga membenarkan konsep domestifikasi ini. Kitab ini juga mengapresiasi pandangan Imam Nawawi (w. 676H/1277M) yang melarang perempuan bepergian secara mutlak tanpa pertimbangan waktu tiga hari sebagaimana dalam teks hadits di atas, jika tanpa ditemani mahram. Perempuan menjadi satu-satunya subyek hukum, yang terkena larangan bepergian tanpa mahram, hanya karena ia berjenis kelamin perempuan.10

Alasan bahwa perempuan adalah penyebab fitnah juga ditulis oleh Wahbah Zuhaili ketika membahas hukum perempuan yang keluar untuk melaksanakan sholat id. menurut hanafiyah dan malikiyah, mereka sepakat bahwa tidak ada rukhsah untuk membolehkan perempuan keluar dalam rangka melakukan shalat jum'at, dua hari raya, dan shalat lainnya. Dasar pendapat mereka adalah ayat 33 surat al-Ahzab11, yaitu:

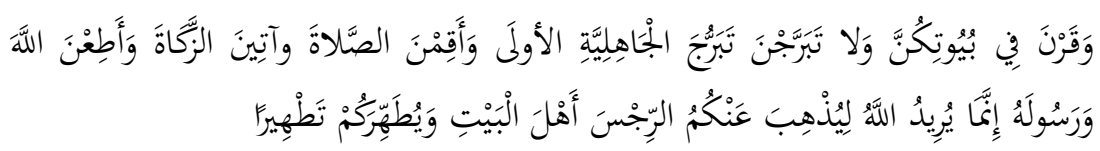

Dan hendaklah kamu tetap di rumahmu dan janganlah kamu berbias dan bertingkah laku seperti orang-orang Jabiliyah yang dabulu dan dirikanlah shalat, tunaikanlah rakat dan taatilah Allab dan Rasul-Nya. Sesunggubnya Allah bermaksud hendak menghilangkan dosa dari kamu, Hai ablul bait dan membersibkan kamu sebersib-bersibnya.

Penjelasan konteks hadits kewajiban mahram dapat ditemukan dalam diskusi Ibn Hazm mengenai haji perempuan yang berangkat tanpa mahram. Menurutnya, perempuan diperbolehkan berangkat dan bepergian haji tanpa mahram sekalipun. Kewajiban mahram ada pada laki-laki untuk berangkat mendampingi perempuan. Jika tidak ada mahram, atau tidak ada yang bersedia menjadi mahram, maka perempuan sama sekali tidak dilarang untuk berangkat haji.

10 Dikutip dari www.rahima.or.id, diakses tangal 2 Juni 2015. Rahima adalah salah satu LSM di Jakarta yang aktif mendiskusikan persoalan-persoalan terkait perempuan. Rahima mempunyai media tulisan yang berjudul Swara Rahima. Penulis sendiri memiliki swara rahima edisi No. 33 Th. X Desember 2010 yang secara khusus membahas tentang memaknai kembali konsep mahram.

11 Wahbah Zuhaili, al-Figh wa Adillatubu, juz 2, (kairo: dar al-fikr, tt), 1389. 
Perempuan bisa dan boleh pergi sendirian berangkat haji tanpa mahram. Siapapun, termasuk suaminya, kata Ibn Hazm, tidak berhak melarang perempuan berangkat pergi haji.12

Pandangan Ibn Hazm ini didasarkan pada beberapa teks hadits lain yang memberikan konteks hadits di atas, yaitu:

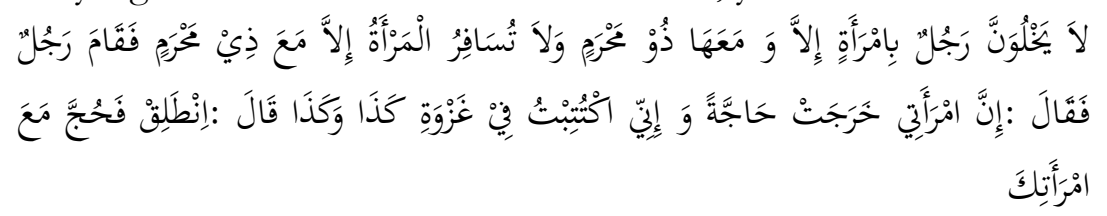

Janganlah sekali-kali seorang lelaki menyendiri dengan seorang wanita kecuali wanita itu disertai mahramnya, dan tidak boleh seorang wanita bepergian kecuali bersama mahram, maka bangkitlah seorang lelaki lalu berkata: 'Sesungguhnya isteriku telah keluar untuk menjalankan ibadah haji, sementara aku telah diwajibkan untuk mengikuti sebuah peperangan', maka beliau bersabda: 'Pergilah dan kerjakan haji bersama isterimu.13

Tetapi pola pikir literal Ibn Hazm memaksanya melokalisasi persoalan ini hanya pada masalah haji saja. Dalam masalah lain, Ibn Hazm melarang perempuan pergi keluar rumah tanpa dampingan suami. Bahkan ia berpendapat, bagi perempuan diwajibkan untuk selalu taat pada suami, dan kewajiban ini jauh lebih tinggi daripada kewajiban-kewajiban lain selain masalah haji. Pola pikir ini tentu saja kembali mengaburkan misi perlindungan perempuan dalam konsep mahram, apalagi pembebasan dari pengekangan.

Mazhab Shafi'i, sebagai salah satu mazhab yang memperjuangkan analogi hukum Islam (qiyas), memiliki kekayaan diskusi persoalan mahram bagi perempuan yang bepergian. Ibn Hajar al-'Asqallani (w. $852 \mathrm{H} / 1448 \mathrm{M}$ ), ulama penda'wah utama mazhab ini, memaparkan berbagai pandangan ulama mazhab terkait alasan hukum dan moral etis terkait persoalan ini. Sayangnya, sedikit sekali orang yang membaca pemaparan ini, sehingga masih banyak yang terjebak pada kewajiban literal soal mahram ini.14

12 www.rahima.or.id, diakses tangal 2 Juni 2015.

13 Muslim bin al-Hajjaj Abu al-Hasin al-Qushairi al-Naisaburi, Sabih Muslim, juz 2, maktabah shamilah, 978 .

14 www.rahima.or.id, diakses tangal 2 Juni 2015. 
Di samping berbagai pandangan yang tetap mewajibkan mahram, ketika memberikan komentar atas teks hadits mahram di atas dalam Kitab Fath al-Bari, Ibn Hajar juga meriwayatkan pandangan berbeda dari dua ulama besar Mazhab Syafi'i, baik teks maupun pandangan ulama terkait mahram dampingan tidaklah tunggal. Imam al-Karabîsî (w. 245H/859M), murid langsung Imam al-Shafi'i, menganggap tidak masalah bagi perempuan pergi berangkat haji atau umrah sendirian selama perjalanan itu aman. Dengan alasan keamanan ini, Imam al-Qaffal (w. 412H/1026M) dan Imam Abu al-Mahasin ar-Rayyani (w. 501H/1107M), berpendapat perempuan boleh bepergian untuk alasan apapun tidak hanya urusan haji. (Ibn Hajar al-'Asqallani, Fath al-Bari, juz 6, hal. 88).15

\section{Analisis Maqasid al-Syariah terhadap Larangan Perempuan Bepergian Tanpa Mahram}

Membahas tentang perempuan dalam perspektif hukum Islam tidak bisa dilepaskan dari sejarah perempuan itu sendiri, terutama jika dikaitkan dengan aturan-aturan seputar perempuan. Sejak dulu, perempuan menjadi objek pembahasan yang selalu menarik untuk didiskusikan. Ini tidak terlepas dari dinamika aturan seputar perempuan yang terkadang lebih menjadikan perempuan sebagai kelas kedua setelah laki-laki sehingga aturan-aturannya pun terksesan diskriminatif.

Setelah kedatangan Islam, martabat kaum perempuan mulai diangkat dan dimuliakan secara bertahap. Diskriminasi terhadap perempuan mulai diminimalisir, bahkan perempuan juga mempunyai hak-hak tertentu di dalam kehidupan. Begitulah adilnya Islam terhadap kaum wanita dan telah membebaskan mereka dari diskriminasi yang telah sekian lama membelenggu diri mereka.

Walaupun begitu, ada beberapa aspek hukum Islam yang dianggap tetap menyudutkan perempuan jika dilihat dari pandangan manusia modern saat ini, apalagi jika dikaitkan dengan konsep Hak Asasi Manusia. Salah satu yang menjadi pembahasan penting dalam kajian ini adalah tentang larangan perempuan melakukan perjalanan tanpa mahram sebagaimana banyak dijelaskan hadis dalam kitab Sahih Bukhari dan Muslim.

15 Ibid. 
Membaca hadis-hadis tentang pelarangan perempuan bepergian tanpa mahram tidak bisa dibaca secara tekstual. Perlu kajian yang lebih mendalam tentang kondisi sosial pada waktu hadis itu diucapkan sehingga hadis diatas bisa dikontekstualisasikan dan direaktualisasikan pada zaman sekarang. Pemahaman terhadap kondisi inilah yang nantinya bisa dtarik kesimpulan tentang maksud dan tujuan (maqasid al-syariah) larangan tersebut diberlakukan. Kesimpulan tentang maksud dan tujuan ini bisa dijadikan dasar untuk memberlakukan hadis di atas jika diapliaksikan pada zaman sekarang. Dalam kajian maqasid al-syariah, harus ada kejelasan antara mana yang diangggap maqasid dana mana yang dianggap wasail. Konsekuensinya, maqasid bersifat permanen dan tetap, sedangkan wasail bersifat temporal dan bisa berubah.

Secara etimologi, maqasid adalah bentuk plural (jama') dari kata maqsid yang berarti sesuatu yang dituju atau tujuan yang ingin dicapai. Kata al-syariah berarti tempat mengalirnya air. 16 Secara terminologis syariah adalah hukum-hukum Allah yang diperuntukkan kepada manusia yang berisi tentang kebijaksanaan dan kesejahteraan dalam kehidupan di dunia dan di akhirat.

Secara terminologis, maqasid al-Syariah adalah pengertian dan rahasia yang dapat difahami daripada syariat Islam dalam keseluruhan atau sebahagian besar proses pensyariatan.17 Pada definisi yang lain dijelaskan bahwa maqasid al-syariah adalah maksud objektif yang datang dari syariah dan rahasia-rahasia yang diletakkan oleh pembuat syariah bagi setiap hukum-hukumnya.18 Al-Raysuni merumuskan kedua definisi tersebut sebagai objek yang ditentukan oleh syariat agar dicapai bagi kepentingan manusia.19

16 Ahmad al-Raisuni, al-Fikru al-Maqasidi, (Ribat: al-Dar al-Baida', 1999), 13

17 Definisi ini mengutip pendapat Ibn 'Asyur dalam kitab Maqasid al-Syari'ab alIslamiyyah. Lihat Mohamad Zaidi Abdul Rahman, "Aplikasi Maqasid Al-Syari'Ah Dalam Pentadbiran Negara: Satu Tinjauan Sejarah Islam,” Jurnal Figh, No. 12 (2015): 31

18 Definisi ini mengutip pendapat 'Allal al-Fasi dalam kitab Maqasid al-Syari'ab alIslamiyyah wa Makarimuba. Lihat Mohamad Zaidi Abdul Rahman, "Aplikasi Maqasid Al-Syari'Ah Dalam Pentadbiran Negara: Satu Tinjauan Sejarah Islam," Jurnal Fiqh, No. 12 (2015): 31

19 Mohamad Zaidi Abdul Rahman, "Aplikasi Maqasid Al-Syari'Ah Dalam Pentadbiran Negara: Satu Tinjauan Sejarah Islam,” Jurnal Fiqh, No. 12 (2015): 31 
Salah satu tokoh maqasid kontemporer, Jasser Audah, memberikan definisi lain. Menurutnya, maqasid al-syariah adalah kemaslahatan atau kumpulan kemaslahatan yang menjadi tujuan pemberlakuan hukum berdasar penjelasan syari' atau menurut persangkaan kuat seorang mujtahid. Andaikan kemaslahatan tersebut tidak ada maka hukum tidak akan disyariatkan sama sekali.20

Pembagian tentang al-maqasid dan al-wasail merupakan salah satu prinsip dasar dalam kajian maqasid al-syari'ah. Pembagian tentang almaqasid dan al-wasail merupakan salah satu prinsip dasar dalam kajian maqasid al-syariah. Al-Qarafi, salah satu tokoh usul fiqh bermazhab maliki mempunyai perhatian serius tentang kajian al-maqasid dan alwasail yang turunannya membahas tentang sad al-z \ariah. Kajian yang dilakukan al-Qarafi tersebut mempunyai pengaruh yang besar dalam kajian maqasid al-syari'ah.

Pembagian antara al-maqasid dan al-wasail harus dilakukan karena kemaslahatan yang menjadi point penting maqasid al-syari'ah menjadi dasar dari penetapan hukum Islam, sedangkan al-wasail adalah sarana yang mengantarkan untuk merealisasikan maqasid alsyariah. Hal ini sesuai dengan definisi maqasid al-syariah, yaitu kemaslahatan atau kumpulan kemaslahatan yang menjadi tujuan pemberlakuan hukum berdasar penjelasan syari' atau menurut persangkaan kuat seorang mujtahid. Andaikan kemaslahatan tersebut tidak ada maka hukum tidak akan disyariatkan sama sekali.21

Jika melihat hadis tentang larangan di atas, maka sesungguhnya larangan tersebut diberlakukan dalam situasi di mana orang terbiasa bepergian dengan menunggang kuda, unta, ataupun keledai. Mereka melintasi gurun-gurun pasir yang membentang, dan nyaris tak ada penduduk atau bangunan apapun. Bagi perempuan yang bepergian sendirian tentu sangat berbahaya. Meskipun dirinya tidak ditimpa marabahaya, akan tetapi bahaya itu selalu mengancam kehormatannya. 22

20 Jasser Audah, al-Ijtibad al-Maqasidi (ttp, al-Syabkah al-'Arabiyyah li al-Abhas, 2011), 17.

21 Ibid..

22 Tim redaksi, Swara Rabima, No. 33 Th. X Desember 2010, 23. 
Selain alasan geografis, bahwa kehidupan nomaden dan kecenderungan patriarkhis-misoginis pada saat itu masih belum banyak berubah, meski Nabi sudah memeperingatkan berulang kali bahwa manusia pada dasarnya adalah sama sehingga perendahan atas tubuh perempuan dan pelecehan seksual atasnya tidak boleh lagi terjadi.23

Dilihat dari segi konteks sistem sosial-ekonomi, bangsa arab pada abad $7 \mathrm{M}$ dalam skala umum dan global adalah agraris (pertanian), meski tidak berarti tanpa aktifitas ekonomi perdagangan. Oleh karena itu aktivitas kehidupan sehari-hari masyarakat tidaklah sesibuk dan semaju konteks masyarakat pada abad sekarang dengan situasi sosial-ekonomi perdagangan, industri, dan tekhnologi komunikasi atau transportasi.24

Dari berbagai latar belakang diatas (geografis, sosial, dan ekonomi) disimpulkan bahwa alasan di balik larangan (perempuan tidak boleh bepergian seorang diri) adalah kekhawatiran terhadap keamanan perempuan saat bepergiaan seorang diri, tanpa ditemani suami atau seorang mahram. Dalam pernyataan ini seperti ini, hukum kewajiban mahram bagi perempuan bepergian bersifat kontekstual, karena rasio-legis dari dari kewajiban ini adalah untuk memberikan perlindungan dan keamanan kepada perempuan.

Jadi, perintah penyertaan mahram dalam perjalanan perempuan pada dasarnya adalah salah satu mekanisme atau cara melindungi perempuan dari kemungkinan-kemungkinan yang tidak dikehendaki. Dengan kata lain, mekanisme atau cara melindungi perempuan dalam konteks sosial zaman nabi adalah melalui penjagaan individu atau personal laki-laki keluarga dekatnya.

Oleh karena itu, dada dasarnya konsep mahram merupakan konsep perlindungan bagi mereka yang lemah, dalam konteks hadis nabi di atas adalah perempuan. Akan tetapi konsep mahram ini juga bisa berubah menjadi ajaran-ajaran pembatasan dan pelarangan halhal yang remeh. Perbedaan pemahaman ini bisa dijelaskan dari persoalan kesadaran yang timpang dalam melihat perempuan dan mereka yang lemah. Oleh karena itu perlu ditegaskan kembali misi

23 Ibid.

24 Ibid. 
perlindungan dalam konsep mahram, sebagaimana pada awalnya ditegaskan Islam.

Jika dikaji dari perspektif maqasid al-syari'ah, maka maqasid (tujuan) dari pelarangan perempuan keluar tanpa mahram adalah demi terealisasinya keamanan dan kenyamanan perempuan ketika melakukan perjalanan. Ketika perempuan di zaman dulu mengendarai kuda atau unta melintasi gurun pasir yang tandus dan sepi dari penduduk, maka ada kehawatiran akan terjadi tindak kriminal yang bisa membahayakan perempuan. oleh karena itu, keberadaaan suami, ayah, atau mahram lainnya adalah salah satu mekanisme perlindungan yang tepat untuk menjaga keamanan perempuan.

Menurut Jasser Audah, tujuan atau prinsip (maqasid) bersifat permanen dan tidak berubah, sedangkan sarana (wasail) bersifat temporal dan bisa berubah-rubah.25 Pada kasus ini, tujuan keamanan dan kenyamanan perjalanan perempuan sifatnya mutlak harus teralisasi, karena hal tersebut adalah maqasid al-syariah yang harus ada dalam perjalalan perempuan. Apapun kondisinya, kapanpun dan di mana pun berada, tujuan keamanan dan kenyamanan perjalanan perempuan haruslah menjadi tujuan utama dalam perjalanan perempuan, karena maqasid al-syariah sifatnya permanen dan tidak berubah. Baik pada masa ketika hadis tersebut diucapkan Rasulullah Saw, ataupun pada masa sekarang, tujuan tersebut tetap harus terjaga selama-lamanya.

Sedangkan wasail pada larangan perempuan tanpa mahram adalah adanya mahram berupa suami, ayah, atau mahram lainnya. Artinya, penyertaan mahram dalam perjalanan perempuan pada dasarnya adalah salah satu mekanisme atau cara melindungi perempuan dari kemungkinan-kemungkinan yang tidak dikehendaki. Dengan kata lain, mekanisme atau cara melindungi perempuan dalam konteks sosial zaman Nabi adalah melalui penjagaan individu atau personal laki-laki keluarga dekatnya.

25 Jasser Audah, Al-Maqasid untuk Pemula, terjemah oleh 'Ali Abdelmon'im (Suka Press, $\mathrm{tk} ; \mathrm{tt}), 83$. 
Jika melihat dari beberapa hadis tentang pelarangan perempuan melakukan perjalanan, maka mahram yang dimaksud adalah mahram sebagaimana penjelasan dalam ilmu fiqh, yaitu:

1. Mahram kekerabatan

a. Ayah, kakek dan seterusnya ke atas, baik dari pihak ayah maupun ibu.

b. Anak laki-lakinya, anak laki-laki puteranya, anak laki-laki puterinya dan seterusnya ke bawah.

c. Saudara laki-laki (seayah seibu), saudara laki-lakinya yang seayah dan saudara laki-lakinya yang seibu.

d. Anak laki-laki saudara laki-laki sekandung, anak laki-laki saudara laki-lakinya yang seayah dan anak laki-laki saudara laki-lakinya yang seibu.

e. Anak laki-laki saudara perempuan yang sekandung (seibu seayah), anak laki-laki saudara perempuannya yang seibu.

f. Pamannya (saudara laki-laki ayahnya) baik saudara sekandung atau saudara laki-laki ayah yang seayah atau saudara laki-laki ayah yang se-ibu.

g. Saudara laki-laki ibu, baik saudara se-kandung atau saudara laki-laki ibu yang seayah, atau saudara laki-laki ibu yang seibu. 26

2. Mahram karena hubungan persusuan

Mahram seorang wanita karena persusuan sama dengan mahramnya karena hubungan kekerabatan

3. Mahram (bagi seorang wanita) karena pernikahan

Mahram bagi seorang wanita karena sebab pernikahan adalah:

a. Anak laki-laki suami dan putera-puterinya, putera-putera (anak laki-laki) dari anak perempuan suami dan seterusnya ke bawah, sama saja apakah mereka itu dari isteri yang sebelumnya (yang telah diceraikan) atau masih dalam ikatan perkawinan dengan atau dari isteri yang sesudahnya.

b. Ayah suaminya (mertua laki-lakinya), kakeknya dan seterusnya ke atas, sama saja apakah kakeknya itu dari pihak ayah suami atau ibu suaminya.

26 Muhammad Nawawi, Taushib 'ala Ibni Qasim, (Surabaya: Mahkota, tt), 201. 
c. Suami anak perempuannya (menantu laki-lakinya) dan suami cucu perempuannya, baik cucunya itu dari anak laki-lakinya atau dari anak perempuannya, dan seterusnya ke bawah.

d. Suami ibu dan suami nenek dan seterusnya ke atas, namun demikian suami tersebut tidak bisa menjadi mahram bagi anak-anak perempuan isterinya, hingga dia telah mengumpuli isterinya tersebut. Jika dia telah mengumpulinya barulah dia menjadi mahram bagi puteri isterinya dan puteri cucunya, baik puteri itu dari suami sebelumnya atau suami sesudahnya, meskipun nantinya dia menceraikan isterinya itu. Jika dia hanya sekedar menjalankan akad nikah dengan seorang wanita, lalu dia menceraikannya sebelum mengumpulinya, maka dia tidak bisa menjadi mahram bagi anak perem-puan dan cucu perempuan mantan isteri-nya tersebut. 27

Berdasar perincian mahram di atas, maka merekalah yang bisa mendampingi perempuan ketika akan melakukan perjalanan, sebagaimana dijelaskan dalam hadis dari 'Abdullah bin 'Umar, bahwasanya Nabi SAW bersabda:

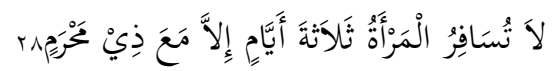

Tidak boleh seorang wanita mengadakan perjalanan selama tiga hari, kecuali bersama mahram.

Selain mahram, suami juga bisa menjadi pendamping perjalanan perempuan. Hal ini dijelaskan dalam dua hadis Nabi berikut, yaitu:

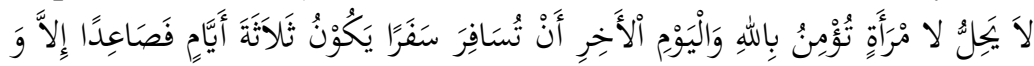

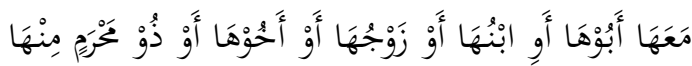

Tidak halal bagi seorang wanita yang beriman kepada Allah dan hari akhir untuk mengadakan perjalanan yang memakan waktu selama tiga hari lebih, melainkan ia harus didampingi oleh ayahnya, anaknya, suaminya, saudaranya, atau mahramnya.29

27 Sayyid Sabiq, Fiqh al-Sunnah juz 1 (Kairo: al-Fathu li al-I'lam al-'arabi, tt), 249. 28 Abi Abdillah Muhammad Bin Isma'il Al-Bukhari, al-Jami' al-Sabih, , juz 4, Maktabah Shamilah, 331.

29 Muslim bin al-Hajjaj Abu al-Hasin al-Qushairi al-Naisaburi, Sabih Muslim, juz 2, Maktabah Shamilah, 977. 
Berdasar kajian di atas, maka wasilah (media atau perantara) agar tujuan keamanan dan kenyamanan perjalanan perempuan bisa tercapai adalah adanya fisik mahram atau suami yang mendampingi perempuan selama perjalanannya. Adanya pendampingan ini diharapkan bisa memberi jaminan keamanan bagi perjalanan perempuan dari gangguan-gangguan apapun, baik dari gangguan manusia ataupaun lainnya. Walaupun pada hakikatnya tidak ada seorangpun di dunia ini yang bisa menjamin keamanan dan keselamatan perjalanan seseorang karena pada hakikatnya Allah yang memberi jaminan, akan tetapi dengan adanya mahram atau suami yang mendampingi merupakan bentuk usaha agar keamanan perjalanan perempuan bisa tercapai.

Lalu bagaimana melihat situasi dan kondisi masa sekarang, baik dari segi geografi, sosial, mapun ekonomi? Dewasa ini peradaban masyarakat modern telah jauh berubah dan berbeda dengan situasi, zaman, dan peradaban ketika hadis mahram muncul di dunia arab pada awal-awal Islam. Komunikasi dunia hari ini berada dalam zaman tekhnologi komunikasi dan transportasi yang teramat canggih. Kampung-kampung pun telah banyak yang menjadi kota dengan segala infrastrukturnya yang jauh lebih lengkap dari pada sebelumnya. Tingkat mobilitas manusia begitu cepat. Ruang-ruang kerja sangat terbuka . bahkan relasi dan komunikasi antar masyarakat dunia sekan tidak lagi tersekat oleh ruang-ruang geografis.

Oleh karena itu, dalam konteks sosial, ekonomi, kebudayaan yang jauh telah berubah ini, maka konsep mahram yang pada awalnya dipahami dan diformat sebagai person atau individu, seharusnya mengalami perubahan konsep dan format dengan tetap mempertahankan esensinya berupa perlindungan dan penjamin keamanan bagi seorang perempuan.

Di sinilah menurut kami urgensitas mengetahui ilmu-ilmu umum untuk membantu mempertajam analisis maqasid al-syari'ah ketika dihadapkan pada realitas kekinian. Maqasid al-syariah akan sangat membutuhkan keilmuan yang terkait dengan pengetahuan sosial, ekonomi, geografi, dan lainnya sebagai alat bantu mengetahui objek kajian yang sedang dibahas dan diteliti. Bagaimana akan mengetahui sistem ekonomi-sosial suatu masyarakat jika tidak pernah tahu sosiologi atau ekonomi. 
Selanjutnya, ketika kondisi telah berubah, maka wasilah "kewajiban ditemani mahram atau suami" bisa diganti dengan wasilab lain yang secara faktual bisa memenuhi tujuan perlindungan dan keamanan yang diperlukan. Jika maqasid bersifat permanen dan tidak bisa berubah, maka wasail mempunyai sifat temporal dan berubah-rubah seusai situasi dan kondisi.30 Jika dikaitkan pada zaman kita sekarang, untuk bepergian jauh, orang bisa menggunakan pesawat, maupun kereta api, yang dapat menampung penumpang dengan jumlah banyak dengan jaminan keamanan tertentu. Karenanya, seorang perempuan tidak merasa khawatir lagi untuk bepergian seorang diri. 31

Mengganti wasilab berupa "pendampingan mahram atau suami" dengan wasilah lain tentunya sesuai dengan konsekuensi pembedaan antara maqasid dan wasail. Menurut al-Raisuni:

1. Umat Islam harus mempertahankan usahanya untuk merealisasikan maqasid syariah. Sebaliknya, dalam memperlakukan wasail sebagai sarana maqasid, umat Islam dituntut untuk mempermudahnya dan tidak boleh mempersulit sehingga wasail tersebut bisa merealisasikan maqasid yang dituju. Umat Islam tidak boleh mempersempit ruang gerak wasail apalagi jika menghalangi terealisasinya maqasid. 32

2. Ada peluang bagi wasilab lain untuk menggantikan wasilah asal jika wasilah lain tersebut bisa menggantikan posisi wasilah asal, atau bahkan lebih cocok dan kontributif untuk merealisasikan maqasid. Oleh karena itu, wasilab asal bisa diganti atau bahkan harus diganti dengan wasilah lain jika lebih prospektif untuk merealisasikan maqasid. 33

Perubahan satu wasilah dengan wasilab lain juga sesuai dengan penjelasan kaidah fiqh, لا ينكر تغير الأحكام بتغير الأزمان (tidak bisa diingkari bahwa perubahan hukum disebabkan karena perubahan

30 Al-Raisuni, al-Fiker al-Maqasidi Qawa'idubu wa Fawa'idubu (Ribat: al-Dar al Baida', 1999), 83

31 Ibid, 24.

32 Ibid, 86.

33 Ibid, 87 
zaman).34 Oleh karena itu bisa disimpulkan bahwa jika perlindungan dan pemberian keamanan perempuan adalah esensi pensyariatan mahram, maka penciptaan situasi atau ruang serta perumusan mekanisme yang kondusif bagi perlindungan terhadap perempuan haruslah menjadi perhatian utama.

Lalu wasilah apa yang bisa menjadi alternatif pengganti dari wasilah "kewajiban didampingi mahram"? Melihat zaman sekarang, ada banyak alternatif wasilah yang bisa merealisasikan maqasid perlindungan keamanan perjalanan perempuan. Mekanisme modern bagi konsep perlindungan masyarakat baik secara individu maupun kolektif antara lain melalui aturan-aturan hukum, perundangundangan, kebijakan-kebijakan publik, petugas keamanan yang profesional, sekolompok teman, budaya dan kondisi yang membuat aman dan nyaman, dan konsep perlindungan lainnya yang membuat perjalanan perempuan aman dan nyaman. 35

Jika melihat kondisi saat sekarang tentang keamanan dan kenyamanan perempuan melakukan perjalanan, maka sebagian perempuan merasa aman dan nyaman bersama suami atau mahram jika bepergian terutama ke tempat jauh. Tapi sebagian perempuan lain menyatakan bahwa terkadang di tetap merasa aman dan nyaman melakukan perjalanan sendirian tanpa didampingi suami ataupun mahram. Bahkan dalam keadaan tertentu, perempuan merasa lebih nyaman bepergian sendirian tanpa harus ada siapapun yang mendampinginya, seperti ketika akan belanja barang untuk kebutuhan perdagangan, dan juga ketika pergi ke luar kota untuk kuliah bagi yang belum menikah.

Melihat kesimpulan di atas, maqasid utama dari keharusan adanya mahram atau suami yang mendampingi perjalanan perempuan (yaitu perlindungan keamanan dan kenyamanan perjalanan perempuan) tetaplah menjadi perioritas utama yang harus diperhatikan oleh siapapun, khususnya bagi perempuan yang melakukan perjalanan. Sedangkan hadirnya fisik mahram atau suami yang mendampingi perempuan adalah satu wasilah agar maqasid tersebut bisa terealisasi.

34 'Amad 'Ali Jum'ah, al-Qawaid al-Fiqhiyyah al-Muyassarah, (Ardan: Dar al-Nafais, 2006), 68.

35 Tim redaksi, Swara Rabima, No. 33 Th. X Desember 2010, 25. 
Jika melihat kondisi sekarang, maka wasilah berupa hadirnya fisik mahram atau suami yang mendampingi perjalanan perempuan bisa ada dua kemungkinan. Kemungkinan pertama adalah wasilab tersebut tetap dibutuhkan dan harus ada jika perjalanan perempuan dirasa tidak aman kecuali harus didampingi suami atau mahram. Pada kondisi keamanan yang kurang terjamin tanpa hadirnya suami atau mahram, maka hadirnya suami atau mahram merupakan wasilah yang harus ada demi tercapainya maqasid, yaitu berupa perlindungan keamanan dan kenyamanan saat perempuan bepergian.

Akan tetapi jika di suatu kondisi di mana perjalanan perempuan terjamin keamanannya, atau menurut keadaan normal perjalanan siapapun termasuk perempuan dianggap aman dan nyaman, maka hadirnya fisik suami atau mahram tidak menjadi kewajiban karena digantikan dengan wasilah lain berupa mekanisme pemberian keamanan melaui profesionalisme aparat keamanan yang siap bertugas kapanpun dan di manapun, aturan yang melindungi perempuan, lingkungan dan kondisi yang kondusif sehingga perjlanan perempuan bisa aman dan nyaman, dan mekanisme lain yang bisa menggantikan posisi hadirnya fisik suami atau mahram. Bahkan jika suatu saat kondisi sangat mencekam dan keamanan tidak terkendali, maka perempuan di larang melakukan perjalanan meskipun didampingi suami atau mahram. Begitu pula sebaliknya, jika kondisi perjalanan sangat terjamin keamanannya, maka perempuan boleh melakukan perjlanan tanpa suami atau mahram.

\section{Penutup}

1. Ada beberapa hadis yang menjelaskan tentang perjalanan perempuan, diantaranya

a. Dalam riwayat Muslim dari hadits Abu Said al-Khudri, Rasulullah SAW bersabda:

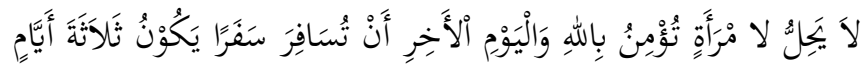

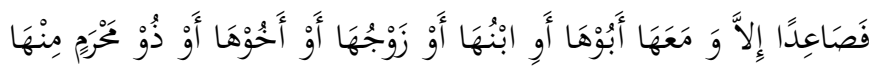

b. Hadits 'Abdullah Ibnu 'Abbas, ia berkata: "Aku mendengar Rasulullah SAW berkhutbah, beliau berkata: 


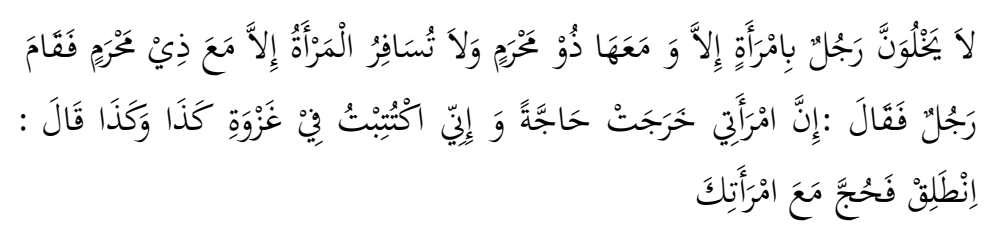

c. Pada hadis ini juga menjelaskan tentang larangan seorang perempuan Rasulullah SAW bersabda:
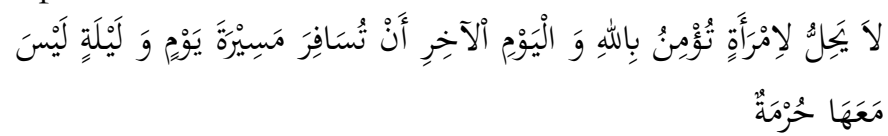

2. Alasan di balik larangan perempuan tidak boleh bepergian seorang diri tanpa mahram adalah kekhawatiran terhadap keamanan perempuan saat bepergiaan seorang diri. Dalam pernyataan ini seperti ini, hukum kewajiban mahram bagi perempuan bepergian bersifat kontekstual, karena maqasid alsyari'ah dari kewajiban ini adalah untuk memberikan perlindungan dan keamanan kepada perempuan. Sedangkan perintah penyertaan mahram dalam perjalanan perempuan pada dasarnya adalah salah satu wasilah (cara atau mekanisme) untuk melindungi perempuan dari kemungkinan-kemungkinan yang tidak dikehendaki. Sedangkan wasilah tersebut bisa diaganti dengan wasilah lain berupa mekanisme perlindungan bagi masyarakat, baik secara individu maupun kolektif antara lain melalui aturan-aturan hukum, perundang-undangan, dan kebijakan-kebijakan publik yang bisa membujat perjalanan lebih aman dan terlindungi.

\section{Daftar Pustaka}

Jasser Audah. Al-Maqasid untuk Pemula, terjemah oleh 'Ali Abdelmon'im. Suka Press, tk; tt

Abi Abdillah Muhammad Bin Isma'il al-Bukhari. al-Jami' al-Sabih, , juz 1, maktabah shamilah

Jasser Audah. Al-Ijtihad al-Maqasidi. ttp, al-Syabkah al-'Arabiyyah li al-Abhas $\backslash, 2011$

'Amad 'Ali Jum'ah. al-Qawaid al-Fiqhiyyah al-Muyassarah. Ardan: Dar al-Nafais, 2006

Muhammad Nawawi. Taushih 'ala Ibni Qasim. Surabaya: Mahkota, tt 
Al-Naisaburi, Muslim bin al-Hajjaj Abu al-hasin al-Qushairi. Sabih Muslim, juz 2, maktabah shamilah

Al-Raisuni, Ahmad al-Fiker al-Maqasidi, Qawa'idubu wa Fawa'idubu. Ribat: al-Dar al-Baida', 1999

Sayyid Sabiq. Figh Sunnah, juz 2. Kairo: al-Fathu li al-I'lam al-'arabi, tt Wahbah Zuhaili. Al-Fiqh wa Adillatubu, juz 2. Kairo: Dar al-Fikr, tt Tim redaksi, Swara Rabima, No. 33 Th. X Desember 2010.

www.rahima.or.id, diakses tanggal 2 Juni 2015. 